\title{
The Sustainability of the Portuguese Prison System: A Criminal Justice System in Masculine Form?
}

\author{
Sandra Patrícia Marques Pereira (D) and Pedro Miguel Alves Ribeiro Correia * (D) \\ Centre for Public Administration and Public Policies, Institute of Social and Political Sciences, \\ Universidade de Lisboa, 1300 Lisbon, Portugal; spereira@iscsp.ulisboa.pt \\ * Correspondence: pcorreia@iscsp.ulisboa.pt
}

Citation: Pereira, Sandra Patrícia Marques, and Pedro Miguel Alves Ribeiro Correia. 2021. The Sustainability of the Portuguese Prison System: A Criminal Justice System in Masculine Form? Social Sciences 10: 19. https://doi.org/ 10.3390/socsci10010019

Received: 6 December 2020 Accepted: 8 January 2021 Published: 14 January 2021

Publisher's Note: MDPI stays neutral with regard to jurisdictional clai$\mathrm{ms}$ in published maps and institutional affiliations.

Copyright: (C) 2021 by the authors. Licensee MDPI, Basel, Switzerland. This article is an open access article distributed under the terms and conditions of the Creative Commons Attribution (CC BY) license (https:// creativecommons.org/licenses/by/ $4.0 /)$.

\begin{abstract}
Society has undergone an entire evolution in the field of criminal penalties, as people want to avoid, or ideally to extinguish, crime and consequent victimization. However, the human nature would hardly allow such utopian society to prevail. Hence, as individuals, we do have codes and bylaws that govern our society. The number of male prisoners is considerably higher in comparison to female prisoners. The aim of the present research is to analyze the sex inequality in the Portuguese criminal justice system, as well as to discuss the following questions: (i) Are men suffering from unjustifiable discrimination by the criminal system? Or, (ii) are there any physical and psychological differences between both sexes? A quantitative and qualitative approach was used. A legal framework was created regarding penalty enforcement, followed by a review of the literature approaching themes of criminology, victimization, and sex inequality. To enrich and empirically support this research, the statistics provided by the Directorate-General for Justice Policy of the Ministry of Portuguese Justice are presented, and a descriptive analysis on the evolution of the number of inmates in Portuguese prisons and juveniles detained in educational centers, between 2010 and 2019 was performed. Implications of this study are is discussed to highlight mediation in criminal cases as a neutral future.
\end{abstract}

Keywords: criminality; inmates; sex inequality; criminal justice system

\section{Introduction}

The impact of sex on crime show that women tend to perform less crimes than men (Acale Sánchez 2019). The Portuguese prisoner system presents a serious imbalance in the number of the prisoners when compared by sex. In 2019, the prisons have registered $93.3 \%$ of male prisoners and only $6.7 \%$ of female prisoners (DGPJ 2020). Also, juveniles detained in educational centers present the same tendency, where $89 \%$ of juveniles detained in educational centers are male while $11 \%$ are female.

The existence of such a notorious disproportionality makes this phenomenon susceptible to scientific study. By observing the statistical evidence, the following issues were raised: Are men wronged by the system? Aren't women justly imprisoned? Have the crimes committed by women been classified differently? The numbers are significant and taking into account the possible consequences for the sustainability of the judicial environment and parity in other public administration areas, it is relevant for our society to understand the reasons for such difference and imbalance. The term sustainability applied to the judicial environment has implications regarding the support of the prisons, prison financial resources, or maintenance of the prison system, and confidence in the institutions. Such institutional sustainability applies for the prison system as much as it does for democracy as both can only operate in a viable away if participants, that is the citizens, agree and have a fair insight regarding its legitimacy. Alternately, both systems may turn unsustainable, tyrannous or anarchical (Pereia and Correia 2020).

Thereby, the aim of the present study is to analyze the sex inequality in the Portuguese criminal justice system and to provide the answers to the following questions: (1) Are 
men suffering from unjustifiable discrimination by the criminal system? Or, (2) are there any physical and psychological differences between both sexes? This leads to the reverse hypothesis that rather than discrimination against males in the criminal justice system, the disproportionate statistics of incarcerated males represent rather physical and psychological differences in the sexes.

This research has the following structure: in first instance, the Portuguese legal system is framed at the crime level, proceeding to a theoretical framing divided in two parts: the one concerning the concept of crime, victimology and penalty and, consequently a further research of literature approaching the theme of sex differences in crime. In order to provide an answer to the above-mentioned issues, a qualitative methodological approach has been taken. An analysis of data provided by the Directorate-General for Justice Policy of the Ministry of Portuguese Justice has been carried out regarding official data on the total number of inmates in Portuguese prison by sex (2010-2019), inmates in Portuguese prison establishments by age (2010-2019), and juveniles detained in educational centers by sex and gender (2010-2019). Followed by a content analysis of the Portuguese Criminal Code (Ministry of Portuguese Justice 1995) in terms of the language used in it. Finally, the results achieved are discussed by connecting the theoretical framework to the factual information, outlining conclusions and possible implications of the evidenced scenario for the public administration and the society as a whole. Finally, mediation in criminal cases is approached as a possibility to make a fresh start in a neutral manner for future lines of investigation.

\section{The Portuguese Regulatory Framework}

As civilizations have evolved, that victims have to avoid being victimized have given rise to written criminal statuses, which in turn has brought about the criminal justice system as an enforcer of those statuses (Hoskin and Ellis 2014).

The Portuguese law consecrates the Portuguese Republic as "the sovereign and democratic state governed by the rule of law based on pluralism of expression and democratic political organization with the respect for and guarantee of fundamental rights and freedoms and in the separation and interdependency of powers which would achieve the economic, social and cultural democracy and strengthen the participative democracy"article 2 . We live in a country based on human dignity and popular willingness, committed to building a free, fair, and cohesive society (Constitution of the Portuguese Republic 2005).

As the main task of the Republic, this research stresses the following as stated in article 9 of the Constitution of the Portuguese Republic (2005): “(b) To guarantee fundamental rights and freedoms and the respect by the principles of the democratic state; (d) To promote the welfare and the quality of life of the population and the real equality amongst Portuguese nation, as well as the enforcement of economic, social, cultural, and environmental rights, by transforming and modernizing social and economic structures; (h) To promote the equality amongst men and women".

Portuguese citizens enjoy a number of fundamental rights and obligations, supported by the principle of the university of the rights and duties to which they are subjected to and the principle of the equality, which means that; "1. All citizens have the same social dignity and are equal before the law. 2. Nobody should be privileged, entitled, deprived of any right or should be exempt of any duty on grounds of descent, sex, race, language, territory of origin, religion, political or ideological conviction, level of education, economic situation, social condition or orientation."-article 12 (Constitution of the Portuguese Republic 2005).

The rights to life, personal integrity, freedom and safety are provided in the articles 24 , 25 and 27. No citizen shall be wholly or partially deprived of their freedoms, except when convicted for a criminal offense punishable with prison. It is for the courts to perform a judicial function as administration of justice which would ensure the defense of the legally established rights and interests of citizens. These bodies shall be independent and shall only respond to the law-paragraphs 1 and 2, articles 202 and 203 (Constitution of the Portuguese Republic 2005). 
Contemporary societies state that human rights as the key principle, along with the ethics of the State, are thus awakening to justice the prominent position of the consolidation guarantees on the values universally recognized by society, with particular attention to human dignity. The Criminal Code is not the only instrument available to fight crime, hence it must include in its own coding of the fundamental community values, where penal gaps are the translation of the hierarchy of values established by society (Ministry of Portuguese Justice 1995).

Until the achievement of the status quo, the initial approaches appealed to legal and criminal sentiments of society, as one speaks about invalidity or validity without mentioning constitutionality and unconstitutionality. Every society has a core composed by legal and criminal sentiments (for example: do not kill, do not steal), and consider a crime to be an action which seriously injures or damages a community and deserves a proper punishment. However, nowadays there is a need for the material concept of crime and the need for incrimination of the one who is wrongful.

The crime is viewed as human conduct. Every crime has the same structure. However, no legislative authority does mention its prohibition. The material concept of crime is connected to prediction. To face a crime, we shall consider the following elements: (i) Material conduct or an intervention of the human will through an action or fact, as "there is no crime without fact"; (ii) As described by law, only the law is entitled to provide the definition of a crime, as "there is no crime without law". As provided in the Article 27 of the Constitution of the Portuguese Republic (2005) "no one shall be sentenced except by force of the law that had previously declared an action or an omission as punishable, nor endure security measures which were not previously established by law". The principle of legality is a is a well-defined procedure and duly empowered to protect the democratic rule of law from reliance, predictability and legal certainty, since the published law is assumed to be of common knowledge. Therefore, only the described and declared fact, liable for a punishment can be punished by law (Ministry of Portuguese Justice 1995); (iii) Wrongful action, "there is no crime without guilt"; (iv) Damage to an interest or a protected right, "there is no crime without damage"; (v) The criminalization or decriminalization patterns directly link to the fundamental rights established by the Constitution of the Portuguese Republic (2005), and thus, the Criminal Code (Ministry of Portuguese Justice 1995) follows the system of these rights enshrined in law.

\section{Theoretical Framework}

\subsection{Criminology and Victimology}

Since 1960, the field of criminology and criminal justice has grown as a discipline of major importance, evolving from an offshoot of sociology into an established academic specialization.

The crime, punishment, and subsequent penalties are at the center of the sphere of criminal law. Criminology acts as an empirical and multidisciplinary science and studies the phenomenon of crime, the offender, the victim and the data about the origin and variables of the crime. Criminology intends to detail, understand, expose, and explain the criminal phenomenon (Amaro and Costa 2019).

Criminology is often characterized by preoccupation with the present and limited consideration of the past (Yeomans 2019). "To what extent can the past enlighten the future?" (p. 493). Present-day historical criminology includes complementary historical data to the criminology of the present. Nevertheless, from the methodological point of view, it would be preferable to consider a long-term approach by researching data over several centuries. There are potential advantages in this analysis, such the identification of historical continuities; the understanding of over-time changes in relation to criminal justice; and a method for identifying of instances of historical recurrence (Lawrence 2019).

Alongside criminology, the victimology also gained a major importance after the World War II, when the depiction of the victims was altered (Amaro and Costa 2019). 
The victim shall be defined as "a natural person who has suffered harm, including physical or mental injury, emotional suffering or material loss, which was directly caused by an offence" - article 1, subparagraph 1-and yet, "family members of a person whose death was directly caused by a criminal offence and who suffered harm as a result of the death of their relative" - article 2, paragraph 2, subparagraph 2 (European Parliament and Council of the European Union 2012).

According to Ronel (2015) the victimology is considered as a new, young and developing science, which deals with negative experiences as victimization and pain, possibility of victimization, harm caused by victimization and various responses to these experiences. By being rarely neutral in its morality and values, this science aims for an improvement for victims. There is an importance and concern with the need of the victim to be listened to and heard (Walklate et al. 2019). From the categoric point of view, victimization is a negative experience which is defined as "human-made act that causes harm and suffering and invades into the self of the victim at various levels" (Ronel 2015, p. 6).

Positive victimology seeks to meet this challenge. With the continued positive psychology and positive criminology, positive victimology intends to specify a shift towards greater attention and awareness, taking an approach that would provide social response to victims and their own victimization, positive recovery of victims and their positive integration in society. This approach to positive victimology provides a specific overview: a general movement in a negative to positive imaginary coordinate system. When moving towards the positive pole at any given coordinate, a sense of justice is an important factor that might reduce the impact of the harm (Ronel 2015).

Narrative victimology and narrative criminology concern with particular key issues, such as identity building and the perspective of first-hand experience. Therefore, the veracity of these stories is not at issue, or at least is not a primary focus of the narrative (Pemberton et al. 2019).

These narratives focus on how the individual experiences the harm caused and how that harm was caused and how it relates to the motivations, behaviors and actions of the past. The intention is the key defining element of the experience. An experience of victimization may completely change the life course of the victim, as a brief and short-lived moment can have long-term repercussions. By considering the perspective of the victim, it is an act that should not have happened but nevertheless did, and the fact that it happened is a consequence of human choice, not an element of a causal and automatic sequence and there was a choice of one person to harm another. Critical perspective to victimology (Pemberton et al. 2019) argues that positivistic approaches too easily and unreflectively adopt criminal justice definitions of what constitutes victimization in their queries, and subsequently lump broad, varied and even conflicting experiences of victims under such definitions.

There is a hierarchy of seriousness in the construct of crime and violence. Most ways of measuring hierarchy consist of counts, such as the number of reported crimes, number of prisoners, imprisonment duration (...) because hierarchical, linear, interval measures have not been available. This is a perverse scenario, which may be a concern, as the methods used treat crimes equally, and what tends to happen is that less serious crimes-prostitution, theft-are much more common than more serious crimes-robberies and homicides (Conrad et al. 2010). Thus, how do we build crime hierarchy?

The number of crimes committed does not take into considerations their seriousness. Therefore, there is an inevitable conduction to estimate crime and violence through selfreport surveys. Form the philosophical point of view, this idea leads us to the notion that the seriousness of a crime cannot be an objective and settled attribute, but it varies in accordance with the subjective citizen perception. The logic is that things that are more valued (e.g., human life), are more protected and more punished when violated. Therefore, there is a hierarchy of difficulty based on estimated risk of committing a particular crime. Less risky crimes are done more often and more risky crimes less frequent. Therefore, 
crime seriousness is determined by the value of the object and subsequently the risk in taking it (Conrad et al. 2010).

\subsection{The Difference between Sex in Crime: Literature Evidences}

In order to answer the questions stated before, it is necessary to research existing literature on sex differences in crime, in order to understand whether or not there are physical or psychological differences between the male and female sex. The explanation is focused in two poles, such as biological differences and sex socialization.

An aggressive attitude is a risk factor for violent behavior (Farrington et al. 2016). The basic principle used to understand sex differences in aggressive behaviors is based on the evolutionary theory, where physically aggressive behavior in either sex is the potential benefits which could be achieved through aggression outweigh the potential costs (in terms of death or injury). The sex differences in aggression may be explained either by high rates of male aggression, despite the costs of injury, or by lower rates of female aggression, despite the benefits of successful competition (Boothroyd and Cross 2016).

The psychological disposition associated to high rates of aggression in men was subconsciously postulated to be a certain 'taste for risk' which facilitated aggressive competition but also produced a more diffuse pattern of risky, dangerous behavior. As for the female sex, the competition also exists, but tends to be pursued in a manner which minimizes physical risk This is because women exercise the main burden of parental care, and thus unconsciously create a certain form to safeguard their body, avoiding risky and dangerous competition. Women tend to use indirect and non-physical competitions, committing very few homicides and assaults. Therefore, female arrests for crimes decrease as the danger involved in that crime increases (Boothroyd and Cross 2016).

According to the research performed by Conrad et al. (2010), women tend to commit less crimes than men, and the crimes that women tend to commit are less serious. Major differences can be seen between male adolescents and adult women. This means that these two groups have a very different crime hierarchy. Hierarchy measures for women tend to include less violent and less serious crimes such as "7. Slap Another Person, 15. Forgery Bad Checks, and 29. Traded Sex" (p. 108), whereas male adolescents tend to adopt more serious and violent crimes, such as "22. Hurt Other Need Med Attn, 20. Armed Theft (money), and 23. Armed Theft" (p. 108). This shows that sex differences make a difference in calculating the seriousness of a crime. It is important to observe differences in crime hierarchies, by sex and age, in order to understand that "one size does not fit all" (p. 110), as the interactions of sexes and ages shows a variable interaction.

In crime and violence scenarios, sex and age differences have been established and hailed as two important factors in understanding violence and crime. The preliminary research of Gentle-Genitty et al. (2017) showed that males and older youth tend to commit violent activities most frequently. This research was performed in accordance with previous research showing that males are more likely to engage in violent activities and less likely to report incidents to adults. The literature allows us to understand the aforementioned trend, as men are taught to be "men" and to show, in biological terms, their strong and solid side, fend for themselves and thus unconsciously engage in activities that prove their strength and masculinity, involving physical aggressions. Yet, the female sex has another type of "preference", tending towards non-physical and more subtle aggression (Lee 2009).

According to the evolutionary neuroandrogenic theory, crime is a manifestation and expression of competitive behavior over resources, statuses and mating opportunities. Therefore, according to this theoretical approach, males have been unconsciously selected for specific resources as a result of female preferences for mates who are successful at resource provision. In this way, sex hormones, such as testosterone, have evolved in ways that make male individuals, in biological terms, more competitive by natural selection (Hoskin and Ellis 2014). As people get older, participation in crime tends to decrease. According to the theory, this happens due to the fact that most individuals unconsciously learn throughout time ways to compete in acquiring more effective and legal resources, 
statuses, and mating opportunities, with less risk of negative consequences. The authors describe two propositions: (i) First, males have been favored by natural selection for being competitive regarding the acquisition of resources, statuses and mating opportunities, which in turn results in their victimizing others more than females do. (ii) Second, male sex hormones have evolved in ways that modify brain functioning to make individuals more competitive in biological terms and likely to victimize others.

These two fundamental assertions provide the understanding of human behavior in crime. The evolutionary neuroandrogenic theory deepens the explanation on how male sex hormones influence the brain, thereby promoting competitive behaviors and having consequences on other individuals. A wide array of neurological, cognitive, learning, and emotional factors fostered by male sex hormones interact to impact the probability of violent and criminal behavior patterns. These are the factors which, according to this theory, form the probability of showing criminal behavior.

The majority of crimes can be explained by the motivation to compete, which is a motivation connected to the brain, where male sex hormones act as main elements of guiding the process. Within the framework of thought of this theory, we are discussing thus, a biological difference between sexes. These differences between males and females, are notorious in competitive, impulsive, self-directed and risky behaviors and are especially accentuated after the onset of puberty, when hormone levels surge, particularly among males. The central theme of this theory is that prenatal brain exposure to testosterone and to other male sex hormones contribute to criminality (Hoskin and Ellis 2014). Following the research performed by Wagels et al. (2019), cortisol and testosterone hormones interactively influence aggressive behavior (positive correlation). The testosterone may influence the neural network in decision making during social provocation in males. Therefore, the interaction between hormones and genes may be liable for variation and emotional response to provocation. Hoskin (2017) has focused on the relationship between testosterone levels and criminal offenses. The author questions: How do high testosterone levels promote crime in teenagers and adults?". The lack of cognitive empathy is shown as an important factor in predicting crime, and exogenous testosterone reduces cognitive empathy. Furthermore, the interaction between testosterone and cortisol hormones increases the risk of antisocial behavior.

The preliminary research performed by Romero-Martínez et al. (2016) has concluded that the costs associated to attention deficit disorder and testosterone levels can be indirectly considered as forming elements of aggressive behaviors, considering their effects on the processing of emotional information. With this study, there is a slight deepening of the factors involved in the risks of a person becoming violent (cognitive deficits and hormonal parameters).

The presence of biological differences, which surpass social divergences. As an example, the research performed by Rout (1999) aimed to compare work-related stress, job satisfaction and mental well-being between male and female doctors. The research has concluded that females show positive signs of mental well-being. On the other hand, however, significantly higher levels of anxiety and depression were observed in males. With regard to social support, and according to the theoretical literature on criminal justice, social support is mentioned as a sex-neutral factor, experienced equally between males and females (Cullen 1994). Although, recent studies showed some divergences, in which it was possible to effectively identify differences when examining the social support experienced by imprisoned males and females. According to the recent research performed by Pettus-Davis et al. (2018), while on the one hand men experience higher rates of negative social support, women, on the other hand, experience higher rates of mixed and positive social support as compared to men.

Sex disparity is a very accentuated issue in literature and is focused on aggressive behaviors, biologically associated to hormone levels, such as testosterone and cortisol (Hoskin 2017). The involvement of male individuals in criminal and violent activities, on biological and sex-related grounds, is well established in the literature review, alongside 
the criminological literature on gender, feminism, and liberation hypotheses, as well as the discussion of death penalties and females

The criminological literature on gender, with special attention paid to Cassia Spohn and Dawn Beichner's research (Spohn and Beichner 1999), concludes that even with increases in female imprison, there is predominantly different sentencing of female offenders, since women face lower probabilities of imprison than do men. Moreover, another study concludes that some individualities and constellations of characteristics in the offenders were related to worst punishment penalty, being the categories mentioned in the study the following ones: young black males and Hispanic males (Spohn and Holleran 2006).

Another field important to the discussion is the Feminism and Liberation Hypothesis. The increase of women participation in male-dominated fields (sports, education, workplace) probably led to unconventional practices, e.g., crimes and offences (Adler 1975). Even though Portugal does not have the reality of death penalty, it is relevant to highlight that in other international realities, such as the United Nations of America, female accused were usually addressed in a compassionate form if they fit within the female conception and gender stereotype. Otherwise, if the female accused showed a more masculine posture, a more aggressive male behavior, such as coldness or a lack of remorse, they were handled more severely (Jochnowitz 2016; Streib 2005).

\section{Materials and Methods}

The use of data, or driven data, leads to reflections of potential benefits in investigation and policy establishment. Thus, spatial and temporal data, as well as interactive information, is provided including potential benefits for society. By accessing to increasingly quantifiable constructs, the number of hypotheses to be tested is increased, we are facing a clear advantage in terms of scientific research and, subsequently, in terms of policy establishment. The data and the theory shall work jointly. An approach that brings the two strands into harmony is the wisest (Ozkan 2018).

The present study aims to discusses the following questions: (1) Are men suffering from unjustifiable discrimination by the criminal system? Or, (2) are there any physical and psychological differences between both sexes? This leads to the reverse hypothesis that rather than discrimination against males in the criminal justice system, the disproportionate statistics of incarcerated males represent rather physical and psychological differences in the sexes.

Therefore, besides the literature review presented above, a quantitative and qualitative approach was followed as methodology. Secondary data were used from the official statistics provided by the Directorate-General for Justice Policy (DGPJ 2020), from the Portuguese Ministry of Justice. Namely, official data on the "total number of inmates in Portuguese prison by sex (2010-2019)", "inmates in Portuguese prison establishments by age (2010-2019)", and "juveniles detained in educational centers by sex and gender (2010-2019)". With the secondary data, a descriptive statistical analysis is performed on the Portuguese reality. This was followed by a content analysis of the Portuguese Criminal Code, where the non-sexist language is addressed.

\section{Results and Discussion}

\subsection{Statistics Provided by Justice: Prisoners in Prison Establishments}

When analyzing the statistics provided by the Directorate-General for Justice Policy, from the Portuguese Ministry of Justice we face a controversial phenomenon.

The evolution of inmates at prisons and juveniles at educational centers, it is possible to observe an uneven characterization of prisoners in terms of sex and age (Figures 1-4). The provided data, as of 2010 to 2019, show the following tendency at Portuguese prisons (Figure 1): $94 \%$ of prisoners are male and $6 \%$ of prisoners are female, not existing any major variation in values provided. In 2010, prisons in Portugal registered 10,986 men (94.6\%) and 627 women (5.4), registering similar data in 2019 with 11,934 men (93.3\%) and 859 women (6.7\%) (DGPJ 2020). Regarding gender, from 2010 to 2019, the age brackets of 
25-39 and 40-59 are the prevalent ones (Figure 2). When comparing the prisons scenario with the educational centers (Figure 3), it is possible to assess that the masculine form is also a reality: in 2010, $89.8 \%$ of juveniles detained in educational centers are males, while $10.2 \%$ are female juveniles. Nine years later, the numbers do not change significantly since $89 \%$ are males and $11 \%$ are female. This finding may be supported for the work of Conrad et al. (2010) and Gentle-Genitty et al. (2017), while the more prevalent age bracket is the $16-17$ years old with $61 \%$ of juveniles detained in educational centers (Figure 4).

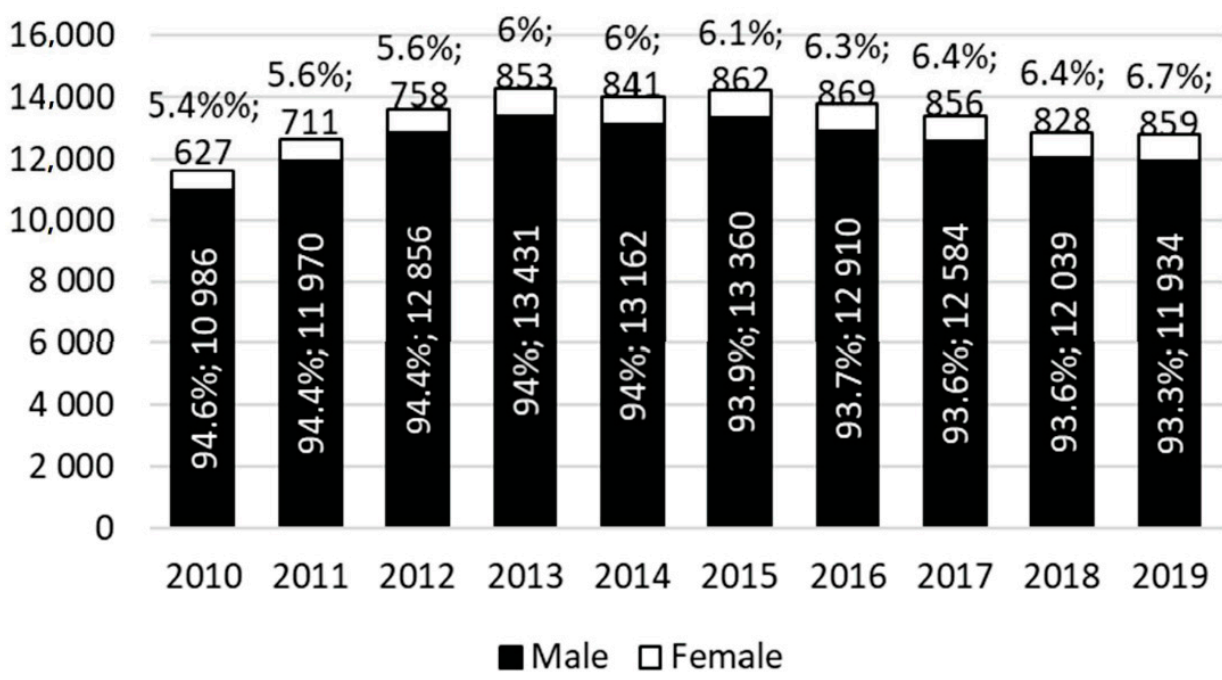

Figure 1. Prisoners in Portuguese prison establishments by sex (2010-2019). Source: own elaboration, based in (DGPJ 2020).

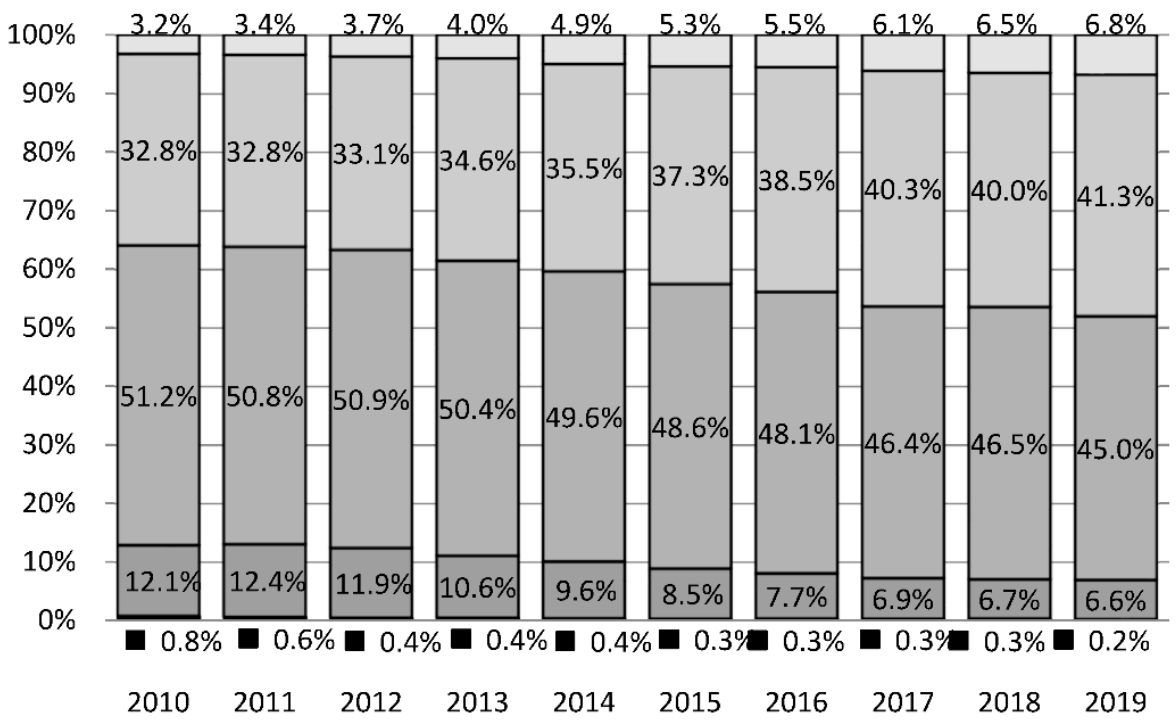

- 16 to 18 years $\square 19$ to 24 years $\square 25$ to 39 years $\square 40$ to 59 years $\square 60$ years or more

Figure 2. Prisoners in Portuguese prison establishments by age (2010-2019). Source: own elaboration, based in (DGPJ 2020). 


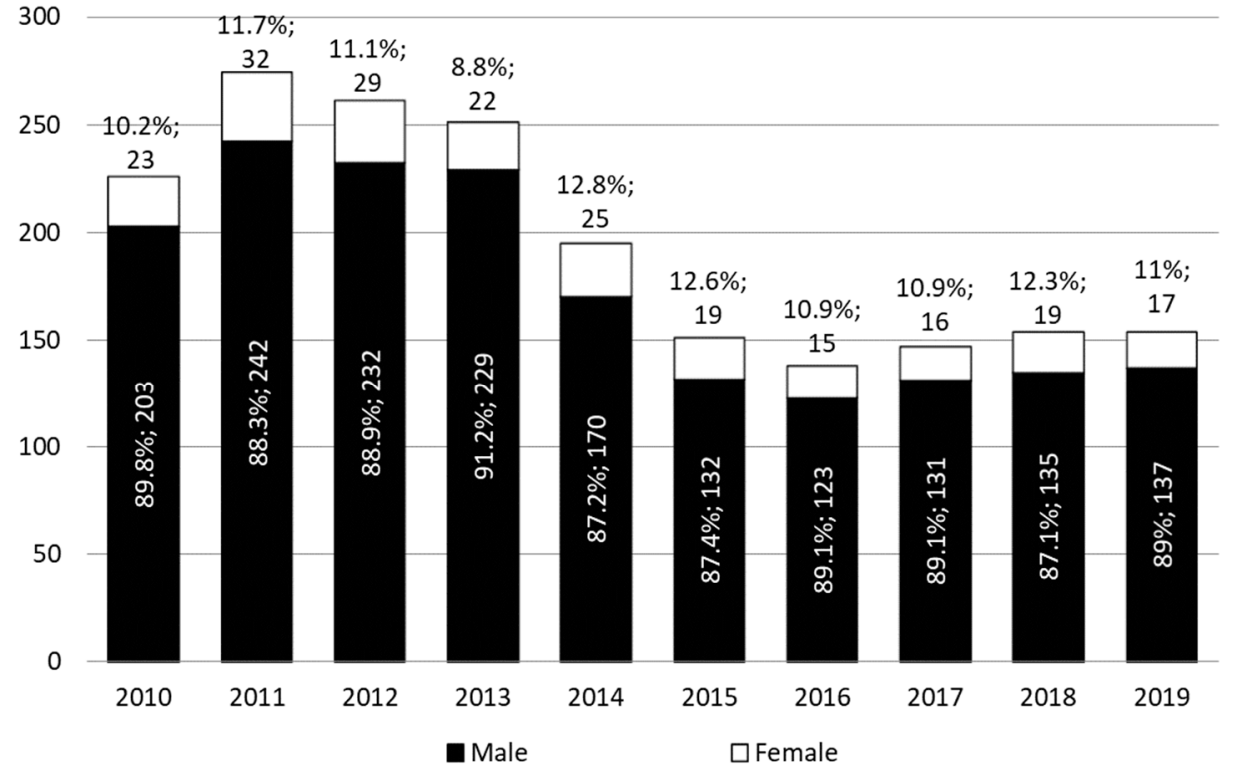

Figure 3. Juveniles detained in educational centers by sex (2010-2019). Source: own elaboration, based in (DGPJ 2020).

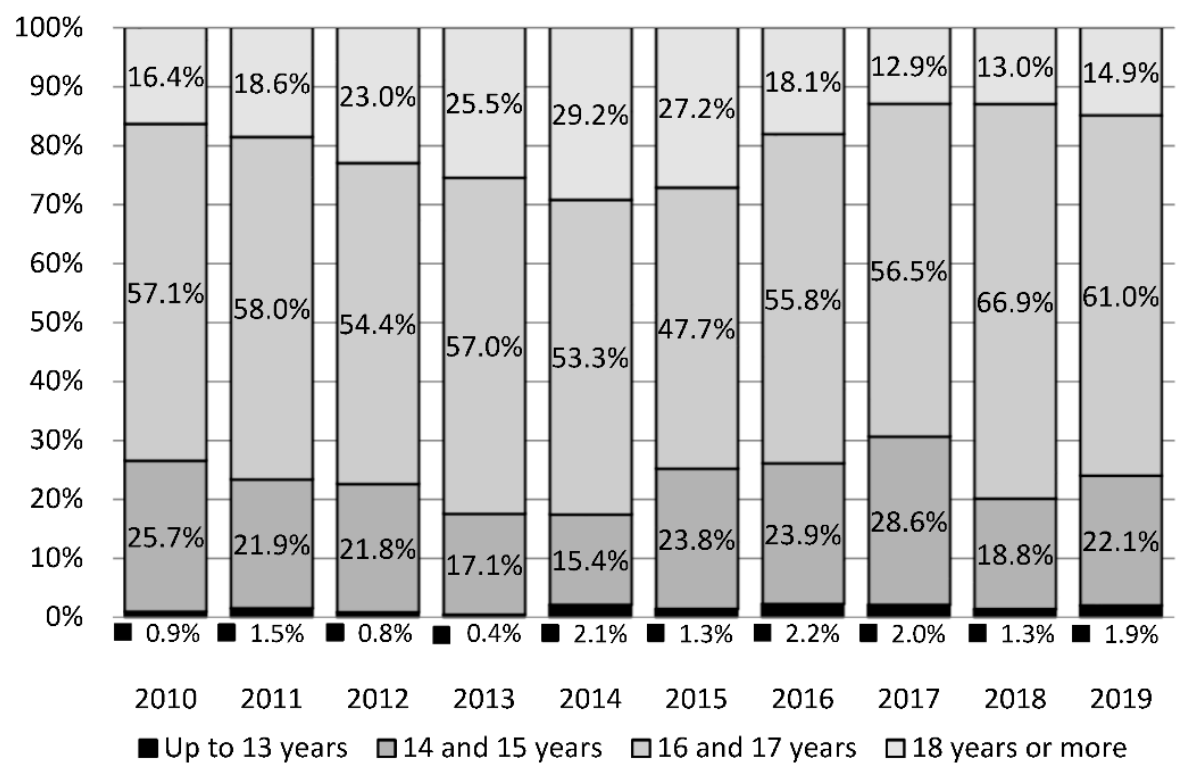

Figure 4. Juveniles detained in educational centers by age (2010-2019). Source: own elaboration, based in (DGPJ 2020).

The existence of parity in the scenario is also verified in other sectors. One illustrative example is the accidents at work, for example, in 2015, it appears to be registered cases of men having more accidents at work than women in the European Union. Thus, analyzing data from the 28 Member States, 2,196,974 men suffered non-fatal accidents at work, while the number of non-fatal accidents at work suffered by women was to 1,012,825 (EUROSTAT 2018). In Portugal, the analyzed data show similar results registering 94,537 men and 39,841 women who suffered non-fatal accidents at work (EUROSTAT 2018).

There is also an unbalanced scenario as for the number of fatal accidents in Portugal. Between 2014 and 2019 the number of male fatal accidents was considerably higher than the number of female fatal accidents. In 2014, 130 men suffered a fatal accident, while only 5 women suffered a fatal accident. In 2019, four women suffered a fatal accident, while 62 men suffered a fatal accident. Another illustrative example of this parity is the number of suicides in Portugal. Deaths caused by this reached more men than women, 
registering 324.7 male death cases per 100 females (INE 2018). In 2017, Portugal registered 1061 suicides, with 287.2 male death cases for every 100 female suicide cases (INE 2019).

\subsection{Content Analysis: The Portuguese Criminal Code}

The present research linked the question of discrimination against males in the criminal justice system to the non-sexist language, since indirectly or even unconsciously may influence the justice system regarding incarceration. In the European Union, Recommendation No R (90) 4 of the Committee of Ministers to Member States on the elimination of sexism from language, works on the call to the Member States of the European Union to eliminate sexism in the language, promoting the use of language that reflects the principle of equality between men and women, and to take into consideration measures that encourage the use of non-sexist language, considering the presence, status, and role of women in society (Council of Europe 1990). This recommendation calls for usage of non-sexist language in legal documents and texts, in public administration and education, in accordance with the constitutional principle of equality.

In this way, a preliminary content analysis was performed to the text of the Portuguese Criminal Code, in order to verify the existence of sexism intonation in language used, and to ensure that the recommendations outlined by the European Union in 1990 are followed. The following terms in the masculine form are most commonly used in Portuguese criminal coding: "The Indicted"—in Portuguese language "O Arguido", "the Offender"—in Portuguese language "O Delinquente", "the Official" —in Portuguese language language "O Funcionário" and, finally "the Officer"—in Portuguese language "O Agente" (Table 1).

Table 1. Terms Enumeration in the Portuguese Criminal Code. Source: own elaboration.

\begin{tabular}{ccc}
\hline & Term Regularly Used & $\begin{array}{c}\text { Number of Appearances in } \\
\text { the Criminal Code }\end{array}$ \\
\cline { 2 - 3 } Portuguese Criminal Code & "The Indicted" & 16 \\
& "The Offender" & 42 \\
"The Official" & 70 \\
"The Officer" & 344 \\
\hline
\end{tabular}

Source: own elaboration.

It was possible to count the following masculine terms in the Portuguese language as listed in the table below. The term "the Indicted" appears 16 times, the term "the Offender" appears 42 times, "the Official" appears 70 times and finally, "the Officer" appears 344 time in the Code. None of these terms appear in the Portuguese feminine form, which proves that the Recommendation No R (90) 4 of the Committee of Ministers to Member States on the elimination of sexism from language is not yet followed by the Portuguese System

\section{Conclusions}

Portugal is a country based on human dignity and popular willingness, committed to building a free, fair, and cohesive society. Portuguese citizens enjoy a number of fundamental rights and obligations, supported by the principle of the university of the rights and duties to which they are subjected to, as well as to the principle of equality, the right to life, personal integrity, freedom, and security. Although, from the statistics results, we conclude this research by considered proved the discrimination against males in the criminal justice system. Sex disparity is a very accentuated issue in the literature and is focused on aggressive behaviors, biologically associated to hormone levels, such as testosterone and cortisol. The involvement of men in criminal and violent activities, for biological and sex-related grounds is well established.

However, while concluding that there is no evidence of male discrimination in the legislation provided, through a content review of the Criminal Code, we shall conclude that it is written in in the masculine form, unlike that established by the Recommendation No $\mathrm{R}$ (90) 4 of the Committee of Ministers to Member States on the elimination of sexism from language, from 21 February 1990. The evidence of sexism is well presented in Portuguese 
legal codification. The used terms are "The Indicted", "the Offender", "the Official" and "the Officer". These terms are never used in the feminine form. From a rational point of view, a neutral language is used or, is the nature of language promoting sexism in penalty application? This can be considered as another nail in the coffin of what is considered politically correct, and may influence, even indirectly, the lower incarceration of women versus men. In times of a global pandemic (Correia et al. 2020a, 2020b), this issue must not be neglected. This can be considered a golden opportunity to test the usefulness of the inclusive sex language (Council of Europe 1990) that we are used to hearing so much about these days. Nevertheless, in case of its failure due to differences which exist in sex characteristics, whether physical or psychological, it would provide a severe injury for feminism.

As a future line for investigation, the neutral future of mediation in Criminal Cause might be a starting point. In Portugal, criminal mediation works on an experimental basis according to the circumscriptions to be designated by Directives of the Minister of Justice, which also defines the other terms of provision of the criminal mediation services. Mediation in criminal prosecution can be the case of legal proceedings, whose procedure depends on a complaint or specific accusation, however it can only take place in criminal proceedings that depend only on a complaint on crimes against an individual or a propertyarticle no. 2, Law no. 21/2007, of 12 June (Assembly of the Portuguese Republic 2007). The mediation process is informal and flexible, conducted by an impartial mediator, who promotes the rapprochement between the indicted and the victim and supports them in an attempt to find a focal point that allows to repair the damages caused by the illegal act and contributes to the restoration of social peace in society. This is a totally confidential and voluntary process, both for the victim and the indicted, who can, at any time, revoke their consent to participate in mediation-article $\mathrm{n}^{\circ} 4$, Law $\mathrm{n}^{\circ} 21 / 2007$, of 12 June (Assembly of the Portuguese Republic 2007).

The usefulness of the inclusive sex language can not only be applied to Restorative Justice but must report it. Thus, it can be generated as neutral if neutrality proves to be useful. The legislator will be able to take advantage of the still embryonic phase of criminal mediation, adopting inclusive language, so that it will be possible to see whether or not there are differences in the data from the long-term perspective.

Also, juvenile gender data shows that the gendered differentiation of offenders include adults and juveniles, thereby, future research should also focus on why there are more female juvenile detained than adults.

Author Contributions: Conceptualization, S.P.M.P. and P.M.A.R.C.; methodology, S.P.M.P. and P.M.A.R.C.; software, P.M.A.R.C.; validation, S.P.M.P. and P.M.A.R.C.; formal analysis, S.P.M.P. and P.M.A.R.C.; investigation, S.P.M.P. and P.M.A.R.C.; resources, P.M.A.R.C.; data curation, P.M.A.R.C.; writing - original draft preparation, S.P.M.P.; writing—review and editing, S.P.M.P. and P.M.A.R.C.; visualization, S.P.M.P. and P.M.A.R.C.; supervision, P.M.A.R.C.; project administration, P.M.A.R.C.; funding acquisition, P.M.A.R.C. All authors have read and agreed to the published version of the manuscript.

Funding: This work was supported by Portuguese national funds through FCT—Fundação para a Ciência e a Tecnologia, under project UIDP/00713/2020.

Institutional Review Board Statement: Not applicable.

Informed Consent Statement: Not applicable.

Data Availability Statement: Further data are available at https:/ / estatisticas.justica.gov.pt/sites / siej/en-us/pages/default.aspx.

Conflicts of Interest: The authors declare no conflict of interest. 


\section{References}

Acale Sánchez, María. 2019. Penal and Custodial Control of Female Criminality in Spain from a Gender Perspective. Social Sciences 8: 52. [CrossRef]

Adler, Freda. 1975. Sisters in Crime: The Rise of the New Female Criminal. New York: McGraw-Hill.

Amaro, Fausto, and Dália Costa. 2019. Criminologia e Reinserção Social. Lisbon: Editor Pactor.

Assembly of the Portuguese Republic. 2007. Law 21/2007 of 12 June. Available online: http://www.pgdlisboa.pt/leis/lei_mostra_ articulado.php?nid=1459\&tabela=leis\&ficha=1\&pagina=1 (accessed on 6 December 2020).

Boothroyd, Lynda G., and Catharine P. Cross. 2016. The Impact of Parenthood on Physical Aggression: Evidence from Criminal Data. Aggressive Behavior 42: 577-84. [CrossRef] [PubMed]

Conrad, Kendon J., Barth B. Riley, Karen M. Conrad, Ya-Fen Chan, and Michael L. Dennis. 2010. Validation of the Crime and Violence Scale (CVS) Against the Rasch Measurement Model Including Differences by Sex, Race, and Age. Evaluation Review 34: 83-115. [CrossRef] [PubMed]

Constitution of the Portuguese Republic. 2005. (LAST Revision). Available online: https://dre.pt/legislacao-consolidada/-/lc/345207 75/view (accessed on 6 November 2020).

Correia, Pedro Miguel Alves Ribeiro, Ireneu Oliveira Mendes, Sandra Patrícia Marques Pereira, and Inês Subtil. 2020a. The Combat against COVID-19 in Portugal: How State Measures and Data Availability Reinforce Some Organizational Values and Contribute to the Sustainability of the National Health System. Sustainability 12: 7513. [CrossRef]

Correia, Pedro Miguel Alves Ribeiro, Ireneu Oliveira Mendes, Sandra Patrícia Marques Pereira, and Inês Subtil. 2020b. The Combat against COVID-19 in Portugal, Part II: How Governance Reinforces Some Organizational Values and Contributes to the Sustainability of Crisis Management. Sustainability 12: 8715. [CrossRef]

Council of Europe. 1990. Recommendation No. R (90) 4 of the Committee of Ministers to Member States on the Elimination of Sexism from Language. Available online: https:/ / rm.coe.int/1680505480 (accessed on 6 December 2020).

Cullen, Francis T. 1994. Social support as an organizing concept for criminology: Presidential address to the academy of criminal justice sciences'. Justice Quarterly 11: 527-59. [CrossRef]

DGPJ-Directorate-General for Justice Policy. 2020. Available online: https:/ / estatisticas.justica.gov.pt/sites/siej/pt-pt/Destaques/20 200529_D69_ReclusosEJovensInternados_2010-2019.pdf (accessed on 30 November 2020).

European Parliament, and Council of the European Union. 2012. Directive 2012/29/EU of the European Parliament and of the Council of 25 October 2012 Establishing Minimum Standards on the Rights, Support and Protection of Victims of Crime, and Replacing Council Framework Decision 2001/220/JHA. Available online: https:/ / eur-lex.europa.eu/legal-content/en/ALL/?uri=CELEX: 32012L0029 (accessed on 6 December 2020).

EUROSTAT. 2018. Accidents at Work Statistics: Statistics Explained. Available online: http://ec.europa.eu/eurostat/statistics_ explained/index.php/Accidents_at_work_statistics (accessed on 30 November 2020).

Farrington, David P., Hannah Gaffney, and Maria M. Ttofi. 2016. Systematic reviews of explanatory risk factors for violence, offending, and delinquency. Aggressive Behavior 33: 24-36. [CrossRef]

Gentle-Genitty, Carolyn, Jangmin Kim, Eun-Hye Yi, Douglas Slater, Beverly Reynolds, and Natasha Bragg. 2017. Comprehensive assessment of youth violence in five Caribbean countries: Sex and age differences. Journal of Human Behavior in the Social Environment 27: 745-59. [CrossRef]

Hoskin, Anthony W. 2017. Male sex hormones and criminal behavior: The predictive power of a two-factor model of organizational androgen exposure. Personality and Individual Differences 108: 86-90. [CrossRef]

Hoskin, Anthony W., and Lee Ellis. 2014. Fetal testosterone and criminality: Test of evolutionary neuroandrogenic theory. Criminology 53: 1-20. [CrossRef]

INE-Instituto Nacional de Estatística-The National Statistical Institute of Portugal. 2018. Causas de Morte 2016. Instituto Nacional de Estatística, I.P.-The National Statistical Institute of Portugal Lisbon. Available online: https://www.ine.pt/xportal/xmain? xpid=INE\&xpgid=ine_publicacoes\&PUBLICACOESpub_boui=320385399\&PUBLICACOESmodo=2 (accessed on 30 November 2020).

INE-Instituto Nacional de Estatística-The National Statistical Institute of Portugal. 2019. Causas de Morte 2017. Instituto Nacional de Estatística, I.P.-The National Statistical Institute of Portugal Lisbon. Available online: https://www.ine.pt/xportal/xmain? xpid=INE\&xpgid=ine_publicacoes\&PUBLICACOESpub_boui=358633033\&PUBLICACOESmodo=2 (accessed on 30 November 2020).

Jochnowitz, Leona Deborah. 2016. Capital Jurors' Receptivity to Mental Mitigation for Female Defendants with Non-Stereotypic Gender Behavior (Kentucky, Missouri). Available online: https:/ / dx.doi.org/10.2139/ssrn.2890559 (accessed on 30 November 2020).

Lawrence, Paul. 2019. Historical criminology and the explanatory power of the past. Criminology E Criminal Justice 19: 493-511.

Lee, Eunju. 2009. The relationship of aggression and bullying to social preference: Differences in sex and types of aggression. International Journal of Behavioral Development 33: 323-30. [CrossRef]

Ministry of Portuguese Justice. 1995. Decree-Law 48/95 of 15 March. Available online: https://dre.pt/web/guest/legislacaoconsolidada/-/lc/34437675/view (accessed on 6 November 2020).

Ozkan, Turgut. 2018. Criminology in the Age of Data Explosions: New Directions. The Social Science Journal 56: 208-19. [CrossRef] 
Pemberton, Antony, Eva Mulder, and Pauline G. M. Aarten. 2019. Stories of injustice: Towards a narrative victimology. European Journal of Criminology 16: 391-412. [CrossRef]

Pereia, Sandra Patrícia Marques, and Pedro Miguel Alves Ribeiro Correia. 2020. Sustainability of Portuguese Courts: Citizen Satisfaction and Loyalty as Key Factors. Sustainability 12: 10163. [CrossRef]

Pettus-Davis, Carrie, Cristopher A. Veeh, Maxine Davis, and Stephen Tripodi. 2018. Sex differences in experiences of social support among men and women releasing from prison. Journal of Social and Personal Relationships 35: 1161-82. [CrossRef]

Romero-Martínez, Ángel, Marisol Lila, and Luis Moya-Albiol. 2016. Testosterone and attention deficits as possible mechanisms underlying impaired emotion recognition in intimate partner violence perpetrators. The European Journal of Psychology Applied to Legal Context 8: 57-62. [CrossRef]

Ronel, Natti. 2015. Why Victimology Should Stay Positive-The Ongoing Need for Positive Victimology. Temida 18: 5-15. [CrossRef]

Rout, Usha. 1999. Sex differences in stress, satisfaction and mental wellbeing among general practitioners in England. Psychology, Health $\mathcal{E}$ Medicine 4: 346-54.

Spohn, Cassia, and Dawn Beichner. 1999. Is Preferential Treatment of Female Offenders a Thing of the Past? A Multisite Study of Gender, Race, and Imprisonment. Criminal Justice Policy Review 11: 149-84. [CrossRef]

Spohn, Cassia, and David Holleran. 2006. The Imprisonment Penalty Paid by Young, Unemployed Black and Hispanic Male Offenders. Criminology 38: 281-306. [CrossRef]

Streib, Victor. 2005. Rare \& Inconsistent: The Death Penalty for Women. Fordham Urban Law Journal 33: 609.

Wagels, Lisa, Mikhail Votinov, Thilo Kellermann, Julian Konzok, Sonja Jung, Christian Montag, Frank Schneider, Albrecht Eisert, Cordian Beyer, and Ute Habel. 2019. Exogenous testosterone and the monoamine-oxidase A polymorphism influence anger, aggression and neural responses to provocation in males. Neuropharmacology 156: 107491. [CrossRef] [PubMed]

Walklate, Sandra, Jane Maher, Jude McCulloch, Kate Fitz-Gibbon, and Kara Beavis. 2019. Victim stories and victim policy: Is there a case for a narrative victimology? Crime Media Culture 15: 199-215. [CrossRef]

Yeomans, Henry. 2019. Historical context and the criminological imagination: Towards a three-dimensional criminology. Criminology $\mathcal{E}$ Criminal Justice 19: 456-74. 